\title{
Marja-Leena Hakkarainen
}

\section{Torjutun paluu \\ Menneen ja nykyisen yhteys Elfriede Jelinekin romaanissa Die Kinder der Toten}

\author{
"Kuolleiden henget, jotka olivat niin kauan kadoksissa, tulevat tervehtimään \\ lapsiaan." (Die Kinder der Toten, 5.) ${ }^{1}$
}

Historiallisiin tapahtumiin liittyvän fiktion kasvava suosio 1900-luvun lopulla on nostanut uudelleen esiin kysymyksen taiteen suhteesta todellisuuteen. Hal Foster $(1996,30)$ pohtii kysymystä teoksessaan The Return of the Real ja mainitsee traumaattisen realismin esimerkkinä kuvataiteen uudenlaisesta kiinnostuksesta todellisuuden esittämiseen. Tutkiessaan tapoja, joilla juutalaisten kansanmurha (Shoah) esitetään nykykirjallisuudessa, Michael Rothberg $(2000,7)$ päätyy termiin traumaattinen realismi, joka ei representoi tapahtumia vaan konstruoi niitä metonymioiden ja viittausten avulla. Kyseessä ei ole suinkaan todellisuudesta etääntyminen vaan pyrkimys vastata samanaikaisesti kolmeen historian asettamaan vaatimukseen: tapahtumien dokumentointiin, representaation rajojen reflektointiin ja reagoimiseen asiasta käytyyn julkiseen keskusteluun (ibid). Keskeinen piirre traumaattisessa realismissa on Rothbergin (2000, 9) mukaan sen tapa nivoa yhteen ärimmäinen ja arkipäiväinen ("the intersection of the everyday and the extreme").

Saksankielisessä tutkimuksessa ja julkisuudessa on kiistelty paljon siitä, voiko holokaustin kaltaisia ääri-ilmiöitä ylipäänsä esittää taiteen keinoin. Realistista representaatiota vastustavat vetoavat usein Theodor W. Adornon varoittaviin sanoihin keskitysleirien estetisoinnista. ${ }^{2}$ Toisen maailmansodan jälkeen ilmestyneet ghettopäiväkirjat ja todistajakertomukset pyrkivät kuvailemaan tapahtumia mahdollisimman realistisesti, kun taas toisen ja kolmannen polven juutalaiskirjailijat eivät ole enää todistajakertojia, vaan he ovat kuulleet tapahtumista kertomuksia ja nähneet erilaisia representaatioita historiankirjoissa, elokuvissa ja romaaneissa (Zangl 2009, 74-75). Shoahin jälkeisten sukupolvien tapa konstruoida menneisyys faktojen ja innovatiivisen mielikuvituksen avulla on Marianne Hirschin $(2012,5)$ mukaan osoitus "jälkimuistista" (postmemory), joka tarkastelee historiaa nykypäivän perspektiivistä. Viime vuosikymmeninä ilmestynyt muisti- ja traumafiktio ei yleensä pyrikään luomaan "todellisuusilluusiota" vaan pikemminkin osoittamaan, miten menneisyys vaikuttaa nykyisyyteen. Erityisesti sukuromaanista on saksankielisessä nykykirjallisuudessa tullut keskeinen muoto kuvata eri sukupolvien suhdetta historian traumaattisiin tapahtumiin (Fuchs \& Cosgrove 2006, 9). 
Itävaltalainen nobelkirjailija Elfriede Jelinek (s. 1946) on useissa näytelmissään käsitellyt varsin kriittisesti sekä kansallissosialistista menneisyyttä että nykypäivän ilmiöitä kuten muukalaisvihaa, talouskriisiä ja median tapaa trivialisoida asioita. ${ }^{3}$ Romaanin Die Kinder der Toten (1995, "Kuolleiden lapset") otsikko viittaa erityisesti Shoahin uhrien jälkeläisiin, mutta sen voi katsoa tarkoittavan laajemminkin kuolleiden merkitystä tuleville sukupolville. Jelinek $(2012,17)$ pitää romaania pääteoksenaan ja sanoo olevansa "haudasta kaivaja" (Toten-Ausgräber), joka itsepintaisesti nostaa päivänvaloon Itävallan osallisuutta toiseen maailmansotaan ja juutalaisten kansanmurhaan. Die Kinder der Toten herätti ilmestyessään hämmennystä ja närkästystä, koska se yhdistää Shoahin traumaattiset tapahtumat kauhukirjallisuuden genreen ja groteskiin komiikkaan. Historiallisten tapahtumien representoinnin sijaan Jelinekin romaani siteeraa satiirisesti erilaisia diskursseja ja viittaa intertekstuaalisesti sekä fiktion eri lajeihin että historiallisiin henkilöihin ja paikkoihin. Se ei myöskään rakennu omaelämäkerrallisille muistelmille ja mielikuville vaan esittää monitasoisen kollaasin, jossa eri aikatasot läpäisevät toisensa. Tutkimuskirjallisuudessa teosta on pääasiassa tarkasteltu suhteessa juutalaisten kansanmurhaan, mutta sitä on tulkittu myös visiona kieleen itseensä kätkeytyvästä aavemaisuudesta (Gsoels-Lorenzen 2007, Lücke 2009). Kuten Jessica Ortner (2012, 85-86) huomauttaa, Jelinekin romaanin kielellinen reflektio ei kuitenkaan ole irrotettavissa sen tematiikasta. Pikemminkin kielelliset rajanylitykset osoittautuvat keinoksi testata todellisuuden representaation tapoja.

Tässä artikkelissa tarkastelen toisen maailmansodan traumaattisten tapahtumien esittämistä ja reflektointia romaanissa Die Kinder der Toten. Kiinnitän erityistä huomiota äärimmäisen ja arkipäiväisen yhdistymiseen teoksen intertekstuaalisissa viittauksissa. Keskeiselle sijalle analyysissäni nousee menneisyyden ja nykyisyyden välähdyksenomainen yhdistyminen, josta Walter Benjamin (1992, 255) käyttää termiä Jetztzeit (nythetki) ${ }^{4}$. Tarkastelen aluksi romaanissa esiintyvän kauhutarinan aikaa ja tilaa ja sen jälkeen viittausten konstruoimaa historiallista aikaa (1940-luku) ja sen sidosta paikkoihin. Lopuksi pohdin romaanin tapaa reflektoida historiallisista tapahtumista käytyä keskustelua 1990-luvun perspektiivistä. Tarkoituksenani on osoittaa, että traumaattinen realismi ei merkitse Jelinekille ainoastaan representaatiosta luopumista vaan todellisuuden performoimista, jolloin romaani avautuu teatterin kaltaiseksi esitystilaksi.

\section{Kauhutarinan aika ja tila}

"Aika koostuu loputtoman pitkistä, raskaista, ruoskansiimoista, joita heilutetaan meidän päämme päällä.” (KT, 651.)

Romantiikan aikana syntynyt kauhukirjallisuuden genre näki aaveet usein kauhua tai pelkoa herättävänä viestinä edellisiltä sukupolvilta. Nykykirjallisuudessa menneisyyden 
aaveiden äkillinen ilmaantuminen on Kathleen Broganin (1998, 4) mukaan merkki "jälleen-muistamisesta" (rememory), joka palauttaa kokijan alkuperäisen kauhun lähteelle. Eurooppalaisessa kauhufiktiossa erilaisten rajatilahahmojen esiintyminen on yleensä liittynyt yksilöiden traumaattisiin kokemuksiin, kun taas etniset vähemmistökirjallisuudet ovat tuoneet kummitusmaisten hahmojen avulla näkyviin ryhmien ja yhteisöjen traumoja (mt, 5). Sana "rememory" esiintyykin tässä yhteydessä afrikkalaisamerikkalaisen kirjailijan, Toni Morrisonin, romaanissa Beloved (1987), jossa lapsiaave konkretisoi orjuuden tuskallisia muistoja. Broganin termi "kulttuurinen kummittelu" (cultural haunting) soveltuu myös luonnehtimaan toisen maailmansodan ja Shoahin aiheuttamien traumojen esittämistä saksankielisessä kirjallisuudessa. Esimerkiksi itävaltalaisen Hans Lebertin romaanissa Die Wolfshaut (1960, "Sudennahka") sodan uhrien ruumishauta kummittelee kylän asukkaille. Saksalaisen näytelmäkirjailija Heiner Müllerin useissa näytelmissä kuten Germania Tod in Berlin (1977, Germania: kuolema Berliinissä 1992) Saksan historian kuolleet heräävät aavemaisesti eloon näyttämöllä. Myös Elfriede Jelinekin romaanissa Die Kinder der Toten kuolleet ilmestyvät keskelle 1990-luvun itävaltalaista arkipäivää. Fyysisen hahmon he anastavat vampyyrien ja zombien kaltaisilta "ei-kuolleilta" (die Untoten).

Jacques Derrida (2006, 9-10) näkee teoksessaan The Spectres of Marx historian aaveiden tulevan esiin silloin, kun aika joutuu pois raiteiltaan. Romaanin Die Kinder der Toten ensimmäisessä luvussa kertoja toteaa, että aika on siirtynyt paikaltaan ja tuonut menneisyyden keskelle nykyisyyttä: "Yhtäkkiä, täysin tarkoituksetta, menneisyys on taas tälllä, mahdotonta pitää siitä" $(\mathrm{KT}, 15)^{6}$. Menneisyyden läsnäoloa konkretisoivat toisaalta kuolleet, jotka haluavat palata elävien joukkoon ja toisaalta yksilölliset rajatilahahmot, jotka toistavat pakonomaisesti omaa kuolemaansa. Romaanissa ei ole lineaarisesti etenevää juonta vaan kerronta muistuttaa traumaa, jossa traumatisoitunut yksilö tahtomattaan palaa samaan ahdistavaan tapahtumaan. ${ }^{7}$ Kuten Sigmund Freud $(2005,111)$ huomauttaa, traumaattinen tapahtuma koetaan vasta jälkikäteen. Näin syntyy toistopakko (Wiederholungszwang), torjutun paluu, mikä murtaa lineaarisen aikakehyksen.

Romaanissa Die Kinder der Toten kauhutarinan todentuntuisuutta hillitsee elokuvan kaltainen kerronta, joka käyttää montaasia, toistoa ja hidastuskuvia. Jelinek (2012, 18-19) on ilmoittanut, että romaanin intertekstuaalisena pohjatekstinä toimii Herk Herbertin ohjaama kauhueloelokuva Carnival of Souls (1962), jossa kolme nuorta naista joutuu auto-onnettomuuteen ja yksi heistä, Mary, palaa elämään aaveiden vainoamana rajatilahahmona. Elokuvassa aaveet valtaavat vähitellen sekä hänen ruumiinsa että mielensä ja vievät naisen lopulta mukanaan. Jelinekin romaanissa on kolme yksilöllistä rajatilahahmoa, jotka ovat kuolleet oman käden kautta (Karin) tai joutuneet auto-onnettomuuteen (Edgar ja Gudrun) sekä joukko nimettömiä zombien kaltaisia 
olentoja. Koska kuolleilla itsellään ei ole enää lihallista hahmoa, heidän on anastettava se ei-kuolleilta, minkä seurauksena syntyy loputon määrä kaksoisolentoja. Kuolleiden paluuseen kuuluvaa aikaa on mahdotonta mitata, sillä kyseessä on "nolla-aika", joka voi tarkoittaa vain yhtä loputtomiin pitkitettyä silmänräpäystä (vrt. Ortner 2012, 98). Tänä aikana esimerkiksi auto-onnettomuudessa kuollut Edgar kokee monta kertaa viimeiset hetkensä, jotka elokuvallinen kerronta esittää hidastettuina toistoina kuten urheilukilpailun televisiointi, jossa ratkaisevaa suoritusta näytetään yhä uudelleen.

Goottilaisen fiktion keskiössä on kysymys kommunikaatiosta elävien ja kuolleiden välillä (Meteling 2010, 187). Jelinekin romaanissa harvoihin elossa oleviin kuuluu alppikylän asukkaita ja turisteja, jotka eivät pysty ymmärtämään ei-kuolleiden hahmojen puhetta ja toimintaa. Keskeinen tapahtumapaikka on pensionaatti Alppiruusu (Alpenrose) ja sen luonnonkaunis ympäristö Itävallan Alpeilla. Horisontaalinen tila avartuu vertikaalisesti kuolleiden olinpaikkaan maan alla ja ilmassa.

Maa tarvitsee ylhäällä paljon tilaa, jotta sen autuaat henget pystyvät kunnolla leijailemaan vetten päällä. Monin paikoin tilaa on yli kolme tuhatta metriä ylöspäin. Niin paljon luontoa on käytetty tähän maahan, että se puolestaan, ehkä maksaakseen velkansa luonnolle, on käyttänyt ihmisiään varsin anteliaasti ja heittänyt ne menemään heti kättelyssä. Maan suuria kuolleita, vain muutamia mainitakseni, ovat Karl Schubert, Franz Mozart, Otto Hayden, Fritz Eugen Viimeinen Henkäys, Zita Zitter, Maria Theresiana, sekä ne, joita Wienin Neustadtin sotilasakatemia tuotti vuoteen 1918 saakka ja Stalingrad 1943 sekä pari miljoonaa kuoliaaksi murskattua. $\left(\right.$ KT, 7.) ${ }^{8}$

Ensimmäinen lause viittaa ironisesti Goethen runoon "Der Gesang der Geister über das Wasser" ("Henkien laulu veden yllä"), jossa kuolleiden henget liikkuvat vetten päällä vuorotellen nousten ja laskien kuin kaste tai sade. Suurmiesten nimet ironisoivat kansallisen historiankirjoituksen kultteja ja paljastavat, ettei romaanissa ole kyse autenttisesta tapahtumien muistelemisesta. Heidän rinnalleen kertoja nostaa maailmansotien ja Shoahin nimettömät uhrit.

Kuolleiden paluu ahdistaa erityisesti romaanin ei-kuolleita, sillä heistä muodostuu portti elävien keskuuteen. Karinin aavistus maan alla olevasta valtavasta Danten helvettiä muistuttavasta suppilomaisesta tilasta yhdistää hänen oman traumaattisen kuolemansa torjuttuun kollektiiviseen traumaan, joka vaatii paluuta päivänvaloon. ${ }^{9}$

Mutta tämä originaali, tämä Karin Ykkönen, kuulee vesihyytymän alla, kuinka syvällä alapuolella oleva lumipeitteistä Alppia suurempi ihmismassa, ihmismassiivi, haluaisi nousta maadimensiostaan, aamunkoiton alapuolella olevasta Disneylandistä, massa jota ei voi ollenkaan käsittää. Karin pyytää epätoivoisesti, että tuo massamainen liikkeelle lähtö, tuo uhkaavaa kammottavuus unohtaisi hänet tai ei ainakaan koskisi häneen. $(\mathrm{KT}, 105 .)^{10}$

Kuolleiden olinpaikan sarkastinen rinnastaminen Disneylandiin yhdistää groteskisti toisiinsa ruumismassan (ääri-ilmiö) ja turismin (arkipäivä). Kertojan kommentit puh- 
taasta luonnosta, terveydestä ja urheilusta saavat ironisen vastapainon tuulen mukanaan tuomasta mädäntyneen lihan hajusta. Samalla ne sitovat aaveiden paluun Itävallan nykypäivään ja sen haluun rakentaa uutta kansallista identiteettiä miellyttävänä ja luonnonläheisenä matkailumaana.

Jelinekin romaanin Die Kinder der Toten elokuvallinen kerronta liittää goottilaiset motiivit kuten myrskyn, rankkasateen ja kuolevat eläimet saumattomasti Alppiruusun pensionaatin idylliseen arkipäivään. Annette Runten $(2008,131)$ mukaan kyseessä on "hybridi laji" (Hybrid-Genre), joka hyödyntää erilaisia kirjallisia traditioita kuten goottilaista romaania, pastoraalia ja barokkiallegoriaa. Intertekstuaalisia viittauksia pitää kuitenkin koossa kertojan ääni, joka selostaa pikkutarkasti yliluonnollisia ilmiöitä ja liittää puheeseensa viittauksia sananlaskuihin, tapakulttuuriin ja kansanlauluihin. Romaanissa toistuva oman ja vieraan, meidän ja muiden, vastakkainasettelu tiivistyy kertojan näennäisen viattomaan kommenttiin: "Me olemme aivan omiemme joukossa, ja missä me olemme, siellä ei ole muita" (KT, 592). ${ }^{11}$

Romaanin loppupuolella muukalaisia alkaa saapua joukoittain alppikylän pensionaattiin. Oudot vieraat herättävät hämmästystä saapuessaan ilman kulkuvälineitä, mutta ainoastaan eläimet vainuavat heissä jotain yliluonnollista (KT, 482-483). Alppiruusun henkilökunta suhtautuu tulijoihin tavallisina turisteina ja kummastelee ainoastaan heidän vanhanaikaisia asujaan ja varusteitaan.

Vastaanottotiskin takana pahvimatkalaukut kasautuvat vuoriksi, tilaa vievää tavaraa, jollaista ei ole pitkään aikaan enää nähty, oikeastaan liian kaupunkilaista tällaiseen maalaismaiseen matkakohteeseen. Useimmat vieraathan suosivat moderneja, kevyitä nailonreppuja, joita he sitten voivat heti käyttää retkillään. Ravintolan emäntä on viimeksi lapsena nähnyt tuollaisia matkalaukkuja auttaessaan naapurikylässä asuvaa tätiään, joka jo silloin vuokrasi huoneita. $(\mathrm{KT}, 517 .)^{12}$

Uudet vieraat majoittuvat vaivatta tiloihin, vaikka matkatavaroiden määrän mukaan pensionaatti on tupaten täynnä. Aavemaiselta vaikuttaa myös tapa, jolla hotellin uudet puhumattomat vieraat jättävät arvoesineensä vastaanottoon ennen sisätiloihin astumista. Yhdistäväksi tekijäksi entisten ja uusien vierailijoiden välillä osoittautuu televisio, kun kaikki hotellin vieraat kokoontuvat katsomaan suosittuja folklore-esityksiä ja visailuja, joilla tuotetaan ja lujitetaan kansallista identiteettiä.

Silmiinpistävä piirre romaanissa Die Kinder der Toten on dialogien puuttuminen. Kuolleiden paluu idylliseen alppikylään välittyy elokuvallisena kerrontana, jota täydentävät kertojan asiasta toiseen rönsyilevät kommentit. Kokonaisuudessa romaanin kerronta muistuttaakin televisio-ohjelmaa, jossa katastrofiuutiset lomittuvat saumattomasti viihteen ja urheiluselostusten kanssa. Kertoja toimii vuorotellen reportterina, joka seuraa tapahtumia paikan päällä, vuorotellen taas television show-ohjelman juontajana. 
Mutta niiden miljoonien ikuisuus, jotka ovat myös kuolleita, joita ei yksikään silmä ole nähnyt. Miten he ovat tulleet tuosta ahtaasta, automaattisesti sulkeutuvasta ovesta, saliin, jossa neuvotellaan heidän uudelleensyntymisestään? Miksi tähän mennessä vain kolme meistä on läpäissyt tämän kokeen? Yksi kuollut sielu on liian vähän puhuakseen niin monen puolesta. (KT, 254. $)^{13}$

Kun romaanin lopussa valtava patomurtuma hukuttaa koko Alppiruusun pensionaatin ja sen lähitienoon, kertoja toteaa, että tapahtumaan liittyy niin paljon selittämättömiä piirteitä, että se on määrätty uutiskieltoon. Ajan ulkopuolelle joutuneen kauhutarinan kytkentä näennäisen objektiiviseen uutisselostukseen alleviivaa median tapaa palauttaa äri-ilmiöt turvalliseen tulkintaan ja vaieta siitä, mistä ei ole lupa puhua, mutta pakottaa samalla lukijan pohtimaan, mitä itse asiassa on mahtanut tapahtua.

Elokuvallinen kerronta ja kauhufiktioiden tehokeinot näennäisesti houkuttelevat lukijaa eläytymään tapahtumiin, mutta samanaikaisesti pakonomaiset toistot ja intertekstuaaliset viittaukset etäännyttävät ja haastavat etsimään tekstistä uusia merkityskerroksia. Kertoja on jo romaanin alussa ohimennen varoittanut lukemisen yllättävyydestä: "Huomio, suojautukaa, nyt tämä teksti alkaa. Se luisuu pois teidän käsistänne." $(\mathrm{KT}, 15 .)^{14}$ Lukijoita puhutellaan myös pitkin matkaa esimerkiksi sanomalla kesken selostuksen "hiljaisuus" tai pyytämällä heitä antamaan aplodeja "salivieraille". Romaanin loppupuolella käykin ilmi, että lukijat ovat osa show-ohjelman yleisöä ja illan päävieraiksi kutsutaan kuolleet. Goottilaisen fiktion aikaan ja tilaan limittyy näin teatterimainen esitys, joka tuo samaan tilaan kertojan, kuolleet henkilöhahmot ja lukijan. Toistuva aikamääre "viisikymmentä vuotta" paljastaa, että vieraat ovat tulleet 1940 luvulta suoraan 1990-luvulle.

\section{Historian aaveet}

"[--] kunnes HÄN, uusi Golem, nousee ja kömpelösti itseään keinuttaen, kääntyen, maata polkien, aloittaa jälleen kerran meidän kansantanssimme.” $(\mathrm{KT}, 97 .)^{15}$

Symbolisen vihjeen romaanin kuolleiden menneisyydestä tarjoaa maininta Golemista, jonka uutta tulemista ennakoidaan jo romaanin alkupuolella. Golemin hahmo liittyy juutalaiseen kabbala-traditioon ja tarkoittaa savesta muovattua jättiläistä, joka osoittautuu luojaansa voimakkaammaksi ja tuottaa tuhoa. Euroopan varhaisten juutalaisvainojen aikana Rabbi Löwin kerrotaan muovanneen savesta suurikokoisen hahmon, joka taisteli menestyksellisesti väkivaltaa vastaan kunnes lopulta kääntyi isäntäänsä vastaan. 1900-luvun alussa saksalaisessa kirjallisuudessa Golemin hahmo nousi esiin nimenomaan tuhoavana voimana, ja sitä on samoin kuin Frankensteinin hirviötä käytetty esimerkkinä ihmisen kohtalokkaasta kyvyttömyydestä hallita luontoa. Shoahin jälkeisessä juutalaiskirjallisuudessa nimi Golem esiintyy usein juutalaisen kulttuurin uudelleen 
elpymisen symbolina. (Baer 2012, 3-4.) Jelinekin romaanissa Golemilla on kaksoismerkitys uhrina ja tuhoajana. Romaanin loppupuolella Golem alkaa jälleen kasvaa saatuaan voimaa uusista ihmisistä: "[--] torso, Golem, joksi liha on niin ihmeellisesti muotoutunut, kasvaa taas kokoon” KT, 645). ${ }^{16}$ Uuden Golemin ilmaantumisen voi nähdä osoituksena paitsi juutalaisen tradition elpymisestä myös historian toistuvuudesta.

Romaanissa Die Kinder der Toten sidos juutalaisten historiaan tulee esiin jo hepreankielisessä motossa lapsiaan tervehtivistä kuolleista. Juutalaisvainojen pitkään historiaan kytkeytyy muun muassa nimeltä mainittu lapsiaave, Anderle von Rinn, jonka juutalaisten uskottiin surmanneen rituaalimenoissaan 1462 ja jota katolinen kirkko on vuosisatojen ajan palvonut marttyyrinä. Antisemitismin noususta 1900-luvun alkupuolella todistavat kertojan selostukset museoista, joissa edelleen talletetaan "mittaustuloksia", jotta ei-arjalaiset tietäisivät, miltä ei olisi saanut näyttää miellyttäk̈kseen "meitä" (KT, 557). Kansallissosialistien rasistisiin juutalaissäännöksiin kuului muun muassa kielto liikkua julkisissa tiloissa. Kertojan äänenpainot näkyvät isoina kirjaimina hänen todetessaan, etteivät vanhukset ja lapset päässeet edes kuumina kesäpäivinä puistoihin ”[--] PÄÄSY KIELLETTY. Vain siksi että ON OLEMASSA.” (KT, 335.) ${ }^{17}$ Konkreettisena todisteena siitä, että rotuerottelu ei rajoittunut vain juutalaisiin vaan ulottui erilaisiin vähemmistöihin kuten romaneihin, homoseksuaaleihin ja vammaisiin, kertoja esittelee wieniläisen sairaalan kellariin talletetun kokoelman vammaisten lasten aivoja, jotka on säilötty lasisiin marmeladipurkkeihin (KT, 563). ${ }^{18}$

Romaanissa Die Kinder der Toten Auschwitzin nimeä ei mainita, mutta se on läsnä lauseessa "Työ tekee vapaaksi” ("Arbeit macht frei" KT, 363) ja isoin kirjaimin painotetussa "SE PAIKKA PUOLASSA" ("DER ORT IN POLEN" KT, 632). Viittausta täydentää ironisen eufemistinen maininta "lomaleiristä", jossa saa työskennellä ilmaiseksi.

Sen jälkeen kun meidän suuret, pehmeät kätemme olivat äidillisesti laskeneet nämä ihmiset, heidät lähetettiin lomaleirille, jossa sai tehdä työtä ilmaiseksi.

TYÖ: pienempi! kalliimpi (kuten euro-banaani). Ensin he asuivat täällä, sitten ulos ovesta. Tästä ovestahan tuli melkein pyöröovi. (KT, 558.) ${ }^{19}$

Yllättävä assosiaatio euro-banaaniin kytkee kansallissosialismin Euroopan unioniin, johon Itävalta liittyi romaanin ilmestymisvuonna. Kuten Jutta Gsoels-Lorentzen (2007, 369) huomauttaa, romaanissa luodaan "anakronististen jännitteiden tiloja”. Kyseessä ei kuitenkaan ole epähistoriallinen ilmaus vaan päinvastoin keino korostaa menneisyyden ja nykyisyyden välistä yhteyttä.

Keskitysleireihin viittaavat myös romaanissa toistuvat maininnat junista, jotka tuovat tekstiin vääjäämättä myös niiden kuuluisan pääteaseman. ${ }^{20}$ Itävallan omasta natsimenneisyydestä muistuttaa Mauthausenin louhos: "Silloiset räjäytykset Mauthausenissa ovat saaneet jättiläismäisen vuorenrinteemme kerta kaikkiaan luisumaan paikaltaan" (KT, 564). ${ }^{21}$ Pohjois-itävaltalaisen Linzin kaupungin lähelle rakennettu Mauthausen 
oli natsi-Saksan keskitysleiri, jossa käytettiin pakkotyövoimaa kivilouhoksilla ja asetehtaassa. ${ }^{22}$ Ironisesti kertoja liittää juutalaisten historiallisen erämaavaelluksen keskitysleireihin huomauttaessaan, että saksalaisten avulla käärmevitsauksesta olisi päästy helposti eroon: "Siinä meidän kaasumme olisi kerrankin ollut paikallaan" (KT, 559). ${ }^{23}$

Saksojen yhdistymisen jälkeen ilmestyi poikkeuksellisen paljon kansallissosialistista menneisyyttä kartoittavia muistelmia, romaaneja ja elokuvia. Etenkin toisen ja kolmannen polven kirjailijat kyseenalaistivat todistajakertojille tyypillisen jyrkän eron uhrien ja pyövelien välillä. Jelinekin romaanissa Die Kinder der Toten kansallissosialistinen ideologia näkyy lukuisina ironisina viittauksina "pohjoiseen rotuun" (KT, 601) ja "viimeiseen blondiin" (KT, 601). Kansallissosialismin johtohahmoja ei esitetä psykologisesti uskottavina vaan pikemminkin koomisina ja niin vähäpätöisinä, että heidän nimensäkin muistetaan ja kirjoitetaan väärin. Hitleriä nimitetään "yläitävaltalaiseksi maanmittaajaksi " ("oberösterr. Landvermesser", 463), jolla on "pitkät veitset". Ilmaisu kätkee sisälleen sekä Kafkan Linnan keskushenkilön että Röhmin murhan ("Die Nacht der langen Messer"). Sana Führer esiintyy useaan otteeseen, mutta se viittaa Hitlerin ohella myös" uusiin johtajiin", etenkin äärioikeistolaisen vapauspuoleen (FPÖ) silloiseen puheenjohtajaan, Jörg Haideriin, joka on tunnistettavissa myös romaanin urheilullisena vuorikiipeilijänä ja kolmannen tasavallan arkkitehtinä (KT, 46). ${ }^{24}$ Monet alluusiot fiktion ulkopuoliseen todellisuuteen tulevat esiin muunnellussa muodossa. Esimerkiksi "Auschwitzin kuolemanenkelinä" tunnetun Josef Mengelen nimi kätkeytyy sanaleikkiin, joka yhdistää toisiinsa "puutteellisuuden" ja "kammottavan mengelemäisyyden" ("Der Mangelhafte wie der grauenhaft Mengelehafte", KT, 395) ja natsien "loppuratkaisun" (Endlösung) pääorganisoija Adolf Eichmann esitellään ironisesti "herra Eichmannina".

Myös herra Eichmannilta, tuolta virkamieheltä, joka on käynyt käsiksi ihmisten muistiin, jottei se enää koskaan heräisi, ovat todennäköisesti hiukset tippuneet päästä ilman, että hän olisi pystynyt saamaan jotakin aikaan tästä toimistokollegoidensa kanssa perustamastaan jättiläisleiristä. Niinpä me elämme leiriyhteisössä vieraiden ruumiiden, silmälasien, hampaiden, matkalaukkujen, nukkien, teddykarhujen kanssa ilman että se tuottaisi meille hyötyä tai haittaa. (KT, 394-395.) ${ }^{25}$

Kuolleiden poissaolosta muistuttavat vain heidän jäljelle jääneet henkilökohtaiset esineensä kuten silmälasit ja lelut. Analysoidessaan Ruth Klügerin ja Charlotte Delbon muistelmia keskitysleireiltä Rothberg $(2000,136,152)$ mainitsee esimerkkinä traumaattisesta realismista vaikuttavat yksityiskohdat kuten keskitysleirin piikkilanka-aitaan roikkumaan jääneet villasukat tai kaasukammion ovelle hylätyn teddykarhun. Jelinek ei rakenna samankaltaisia kuvia arkipäivän ja ääri-ilmiön yhdistymisestä keskitysleirin todellisuudessa vaan korostaa menneisyyden jähmettymistä osaksi arkipäivää siten, että ihmiset edelleen elävät kansallissosialismin perustamassa "leiriyhteisössä". 
Traumaattisessa realismissa yksityiskohdat viittaavat johonkin todelliseen, mutta eivät representoi sitä (Rothberg 2000, 104). Romaanissa Die Kinder der Toten tällaisia keinoja viitata todellisiin tapahtumiin ovat tuli, savu, uunit, kaasu ja tuhka. Esimerkiksi savu ja kaasu kytkeytyvät assosiatiivisesti kaasukammioihin silloinkin kun ne esiintyvät näennäisen viattomissa yhteyksissä kuten esimerkiksi "grillisavu" ja "Citygas light" (KT, 69). (Vrt. Biebuyk 2008, 296.) Rothbergin (200, 104) mukaan asiayhteydestä irrotettu viittaus poikkeaa indekseistä sikäli, että se ei esitä kausaalista syytä tai osaa jostakin kokonaisuudesta vaan "viittaa kammottavaan poissaoloon" ("points to the uncanny absence"). Jelinekin kauhukertomuksessa viittaukset "ihmistuleen" (KT, 199) muistuttavat niistä miljoonista, jotka on väkivaltaisesti poistettu Euroopan maaperältä. Jutta Gsoel-Lorensen (2007, 363) huomauttaakin painokkaasti, että romaanissa ei ole kyse vain aavemaisesta paluusta vaan miljoonien katoamisesta ("not only spectral return but the vanishing of millions").

Jelinekin omaelämäkerrallinen tausta tulee romaanissa selkeimmin esiin kertojan todetessa, ettei hän (kirjailija) halua edustaa uhreja. Romaanin loppupuolella kertoja kohtaa oman isänsä aavevaeltajien joukossa ja mainitsee myös esivanhempansa, joiden hautakivet antisemitistit kaatoivat Wienin juutalaisten hautausmaalla (KT, 602). Keskustelussaan André Müllerin kanssa Jelinek mainitsee, että hänen tsekinjuutalainen isänsä selviytyi Shoahista hengissä, mutta 49 isän sukulaista kuoli keskitysleireillä. (Müller \& Jelinek 2006, 23.) Tämä luku toistuu romaanissa kertojan yhdistäessä Raamatun maininnan taivaan monista asuinsijoista huomautukseen, että hänen isänsä kodista puuttuu 49 ihmistä. Romaanissa mainitaan nimeltä myös Shoahista selviytynyt todistajakertoja Primo Levi sekä Paul Antschel (Paul Celan). Itävallasta Englantiin paennut Sigmund Freud on romaanissa "Sigi", jonka sisaret on viety keskitysleireille (KT, 637).

André Müllerin kanssa käymässään keskustelussa Jelinek valittaa sitä, että juutalaisten mukana Euroopasta katosi myös juutalainen huumori, jonka hän oli oppinut isältään (Müller \& Jelinek 2006, 23). Etnisten vähemmistöjen vitsit ja sanaleikit ovat usein luonteeltaan mustaa huumoria, joka nostaa esiin juuri ne ilmiöt, jotka kauhistuttavat eniten. Teoksessaan Laughing Fit to Kill Glenda R. Carpio $(2008,7)$ huomauttaakin, että etnisessä kirjallisuudessa huumori voi ilmetä tragikomediana, jossa nauru ei ole ilon vaan surun ilmaus. Romaanissa Die Kinder der Toten komiikka ilmaisee paitsi surua myös vihaa ja raivoa. Vitsit ja kielen monimerkityksellisyydellä leikittely ovat nimenomaan juutalaiselle huumorille tunnusomaisia piirteitä (Patha 2010, 28-29). Jelinekin romaanissa ironia ja kielivitsit osoittautuvat tärkeiksi keinoiksi korostaa traumaattisen historian ja arkisen nykypäivän välistä yhteyttä.

Eräs groteskin komiikan tavoite Jelinekin romaanissa on purkaa ja paljastaa kansallissosialistisia myyttejä ja niiden rodullistavaa käyttöä. Kuolleiden paluu 
Alppiruusuun ja sen huoneiden haltuunotto on nähtävissä paitsi kostona heidän omien kotiensa ja omaisuutensa anastamisesta myös viittauksena kansallissosialistien vaatimukseen saada itselleen ja jälkeläisilleen lisää elintilaa (Lebensraum). Juutalaisten kuolleiden ja saksalaisten haamujen yhdistyminen on puolestaan sarkastinen rinnastus ajatukseen saksalais-juutalaisesta symbioosista, jota 1800-luvun valistuksellinen tasa-arvoajattelu esitti keinona rikastuttaa kummankin etnisen ryhmän kulttuuria. Juutalaisten jatkuvan syrjinnän huipentuminen kansanmurhaan osoitti yhdistymisen mahdottomuuden ja sodan jälkeen alettiinkin puhua saksalaisten ja juutalaisten "negatiivisesta symbioosista". ${ }^{26}$ Arno Meteling $(2010,194)$ huomauttaa, että Shoahin uhrien sijoittaminen idylliseen alppimaisemaan luo parodisen viittauksen myös 1900-luvun alussa suosituksi tulleeseen kotiseuturomaaniin (Heimatroman). Synnyinseudun myyttistä menneisyyttä ja idyllistä rauhaa ihailevat kotiseuturomaanit ja -elokuvat tarjosivat kasvualustan kansallissosialistien veren ja maan pyhää liittoa korostavalle Blut und Boden -ideologialle. Sodan jälkeen uudelleen muovailtu kansallinen identiteetti pyrki ankkuroitumaan "viattomiin arvoihin" kuten puhtaaseen luontoon, katolilaisuuteen ja "kodikkuuteen" (Gemütlichkeit). Kuten Jessica Ortner (2012, 90) huomauttaa, kotiseutu osoittautuu Jelinekin romaanissa nekropoliksi, mitä vielä korostaa sen sidos kaupalliseen turismiin.

Rothbergin (2000, 19) mukaan Auschwitzin jälkeen historiakin näyttäytyy traumaattisena sikäli, että jatkumon tilalla on toisto, katkelmallisuus ja pakonomainen paluu. Jelinekin kerronta rakentuu nimenomaan näille elementeille. Kyseessä ei kuitenkaan ole traumafiktio siinä mielessä, että siinä pyrittäisiin kerronnan avulla jälkikäteen merkityksellistämään traumaattisia tapahtumia. Kuten Rothberg $(2000,103)$ toteaa, traumaattisella realismilla on tärkeä pedagoginen tavoite herättää lukijat ajattelemaan asioita uudelta kannalta. Romaanissa Die Kinder der Toten kyseessä ei ole menneisyyden muisteleminen tai kertojan itsensä eheytyminen vaan itsepintainen vaatimus historian jatkuvasta uudelleen määrittelystä.

\section{Muisti ja unohdus}

"Kasvaako hänenkin kätensä haudasta (samoin kuin lapsen), jotta taas tiedetään, mihin hänet on haudattu?” (KT, 258.)

Romaanin Die Kinder der Toten temaattisessa keskiössä on kysymys muistista ja unohtamisesta. Menneisyyden torjumista havainnollistavat alluusiot Grimmin satuun "Das eigensinnige Kind" ("Itsepäinen lapsi”), jossa äiti rankaisee uppiniskaista lastaan hautaamalla tämän maahan. Lapsen käsi kasvaa kuitenkin aina uudelleen maan pinnalle, vaikka äiti kerta toisensa jälkeen hakkaa sen poikki. Jelinek $(2012,8)$ huomauttaa esseessään "Ich als Toten-Ausgräberin" ("Minä kuolleiden haudasta kaivajana"), ettei 
historiaa voi tappaa, koska se tulee aina uudelleen näkyviin. Romaanissa Die Kinder der Toten esimerkkinä torjutun paluusta ovat ei-kuolleet, joita kirjailija ilmoittaa pitävänsä Itävallan historian metaforana (ibid.). Rinnastuksen ironiaa korostaa se, että ei-kuolleet elävät vain nykyisyydessä eivätkä muista mitään menneisyydestään.

Kylmän sodan aikana sekä idässä että lännessä haluttiin unohtaa kaikenlainen yhteistyö kansallissosialistien kanssa, ja Itävalta uskotteli pitkään olevansa "Hitlerin ensimmäinen uhri”, joka ikään kuin vasten tahtoaan joutui vedetyksi kansallissosialistien hirmutekoihin (Lawson 2003, 22). Saksassa tilinteko menneisyyden kannalta käynnistyi 1960-luvun natsioikeudenkäynneissä, mutta Itävallassa syyllisyyskysymys nousi esiin vasta 1980-luvulla kun Kurt Waldheimin toiminta SS-joukoissa tuli julkisuuteen. ${ }^{28}$ Ensimmäisen virallisen myönnytyksen kollektiivisesta syyllisyydestä antoi Itävallan liittokansleri Franz Vranitzky 1991 puheessaan "kuolleiden jälkeläisille" (Gsoel-Lorensen 2007, 361-362). Samaan aikaan sijoittuu myös Jörg Haiderin poliittisen uran nousu osoituksena kansallissosialistisen ajattelun uudelleen elpymisestä ja jopa institutionalisoitumisesta populistisena äärioikeistopuolueena.

Saksassa on 1990-luvulla pitkään ja poleemisesti kiistelty toisen maailmansodan ja Shoahin muistamisen ja muistelemisen merkityksestä (Fuchs \& Cosgrove 2006, 2-3). Kun aikaisemmin painotettiin, ettei tapahtumia saa unohtaa, jotta ne eivät toistuisi uudelleen, alkoivat niin historioitsijat ja poliitikot kuin kirjailijatkin vaatia vapautusta kauhutekojen muistelemisesta ja kollektiivisesta syyllisyydestä. Jelinekin romaanissa kertoja huomauttaa ironisesti, että on turha sanoa "ei-koskaan enää", koska kaikki toistuu jo entiseen tapaan. ${ }^{29}$ Samaan aikaan kuin holokaustin muisteleminen institutionalisoitui, alettiin pitää virallisia muistotilaisuuksia myös kolmannen valtakunnan merkkitapahtumien kunniaksi. Saksan ja Itävallan yhteenliittymän (Anschluss) viisikymmentävuotispäivän kunniaksi 1988 pidetty tilaisuus on taustalla Jelinekin kertojan ennustaessa hilpeiden muistojuhlien dramaattista loppua.

Kuka sitten lieneekin tuhonnut nämä uhrimassat ihmisiä, ei ole ottanut huomioon, ei ole ehkä voinut myöskään tietää, että tulen läpi kulkiessaan nämä saisivat pysyvän voiman, joka nyt kasvaa meissä, jotka vielä olemme täällä ja lähestymme teitä kirjeellisesti, tempaisten ulvovana pyörremyrskynä sinne, missä ei ole muistojuhlia, joissa presidentit ja kanslerit puhuvat, laulavat, juovat ja nauravat. $(\mathrm{KT}, 165 .)^{30}$

Viittaus tulevaan pyörremyrskyyn luo romaaniin uuden aikatason. Romaanin loppupuolella visio apokalyptisestä ajasta voimistuu alluusioilla Uuden testamentin kuvaukseen viimeisestä tuomiosta. Kertojan näkökulma vaihtuu tiheään minä- ja me-muodoista näennäisobjektiivisen selostajan kamerakuvaan. Kollektiivinen me-muoto esiintyy erityisesti ironisissa kommenteissa "meistä saksalaisista ja itävaltalaisista”, selostajana kertoja imitoi median tapaa luoda katsojille illuusio siitä, että he ovat itse paikan päällä tapahtumien silminnäkijöinä. 
[--] historia kulkee yhä nopeammin taaksepäin, enkeli kahlaa vereen upotetussa ja kameran edessä Ariel-Ultralla pestyssä vaatteessa eteenpäin ja me voittajat tarkastelemme toisiamme vastapestyin, pehmeiksi huuhdelluin katsein, kuin ensimmäistä kertaa. (KT, 643.) ${ }^{31}$

Walter Benjamin (1992, 249) näki historian enkelin katsovan silmät kauhusta selällään menneisyyteen samalla, kun paratiisista nouseva myrsky vääjämättä lennätti sitä eteenpäin. Jelinekin visiossa historia itse kulkee taaksepäin ja enkeli joutuu kahlaamaan tulvavedessä. Hänen valkeaksi pesty vaatteensa viittaa Raamatun lupaukseen siitä, että veriruskeatkin synnit voivat muuttua lumivalkeiksi (Jes. 1:18). Romaanissa Jumalan armon tilalla on kuitenkin mainoksista tuttu pesuainemerkki ja valkaisutapahtumaa todistaa televisiokamera. ${ }^{32}$ Historian enkelin ja pesuainemainoksen yhdistelmä nivoo satiirisesti yhteen ääri-ilmiön ja arkipäivän. Kritiikin ensisijaisena kohteena on media, joka vakuuttaa historian veripyykin muuttuvan valkoiseksi, jotta katsojat jälleen kerran tunnistavat itsensä voittajiksi, mutta samalla enkelivertaus vahvistaa Benjaminin (1992, 248) näkemystä historiankirjoituksesta voittajien kertomana tarinana.

Benjaminin historianfilosofisiin teeseihin sisältyy myös ajatus "salaisesta sopimuksesta" sukupolvien välillä. Jokaiselle sukupolvelle on annettu "heikko messiaaninen voima”, josta se on vastuussa menneisyydelle. (Benjamin 1992, 245-246). Matthias Fritsch $(2005,41)$ huomauttaa, että Benjaminin ajatusta messiaanisesta voimasta on usein tulkittu epämääräisessä tulevaisuudessa tapahtuvaksi hyvitykseksi. Kyse ei kuitenkaan ole tulevaisuuden utopiasta vaan siitä, että menneisyyden haasteeseen on vastattava kunakin aikana erikseen (Fritsch 2005, 50-51). Romaanissa Die Kinder der Toten viittaukset tuomiopäivään osoittavat, että ajan raiteiltaan joutuminen merkitsee myös nykypäivän ja tulevaisuuden kohtaamista. Jelinek vaati, että eri painoksissa romaanin sivumäärän (KT, 666) piti pysyä muuttumattomana. Tämä Ilmestyskirjan petoon kytkeytyvä luku antaa ymmärtää, että romaanin nykyhetki on muuttunut ajaksi, jolloin tuomitaan elävät ja kuolleet.

Jelinekin romaanin apokalyptisessä ajassa sidos traumaattiseen realismiin näkyy tavassa, jolla mystinen visio ja arkipäivä sekoittuvat toisiinsa. Itävallan kansallisen menneisyyden ikonina tunnetut wieniläiset hevoskuskit (Fiaker) saavat eteensä Ilmestyskirjan tuliset ratsut: "[--] sieltähän ne tulevat, apokalyptiset ratsut alkuperäisen wieniläisen fiakerin edessä" (KT, 643). ${ }^{33}$ Alppikylän tulva rinnastuu romaanissa unohduksen Lethe-virtaan, jonka vesi muuttuu kiehuvankuumaksi kuin Ilmestyskirjan tulinen järvi (KT, 640). Raamatun kertomukseen maanjäristyksistä, hautojen avautumisesta ja temppelin esiripun repeämisestä (vrt. Mar 15:38 ja Ilm. 8: 1-5) rinnastuvat myös romaanin luonnonmullistukset, joiden alkusyy on Mauthausenin louhosvuoron murtuminen. Aaveiden myötä kaikkialle ilmaantuu kuolleiden hiuksia, joista on myös kudottu temppelin itsestään avautuva esirippu. Hiusmotiivi tuo intertekstuaalisesti kerrontaan Paul Celanin runojen lukuiset alluusiot kuolleiden hiuksiin. Esimerkiksi hänen tunnetussa 
runossaan "Kuolemanfuuga" toistuvat säkeet kultaisista ja tuhkatuista hiuksista: "[--] sinun kultaiset hiukset Margarete / Sinun tuhkatut hiuksesi Sulamith me kaivamme hautaa taivaalle missä et / makaa turhan ahtaasti” (KT, 87). ${ }^{34}$ Myös runon kielikuva taivaalle kaivetusta haudasta rinnastuu Jelinekin kertojan pohdiskeluun, miten savuna ilmaan nousseet ihmiset voisivat palata kuulemaan viimeistä oikeudenkäyntiä.

Derrida (2006, 34) huomauttaa, että Benjaminin näkemykseen messiaanisuudesta kytkeytyy ajatus oikeudesta ja "toisen tulemisesta" ("the coming of the other"). Jelinekin romaanissa selvimpänä esimerkkinä tästä ovat eutanasian uhreiksi joutuneiden vammaisten lasten aivot, joille apokalyptinen aika tarjoaa mahdollisuuden poistua kellarissa säilytetyistä lasipurkeista. He nousevat Wienissä "viimeiseen pikajunaan" ja saapuvat Alppiruusun pensionaattiin vaatimaan oikeutta seuraavilta sukupolvilta. Lineaarisen aikajatkumon katkaisee menneen ja nykyisen yhdistyminen nythetkeksi, johon on Benjaminin sanoin sinkoutunut "messiaanisen sirpaleita" (ks. Benjamin 1992, 255).

Romaanissa Die Kinder der Toten esitetty maailmanlopun visio poikkeaa selvästi sekä goottilaisen fiktion imitoinnista että historian dokumentoinnista metonymioiden ja alluusioiden avulla. Allegorian kiinteä sidos poliittiseen satiiriin muistuttaa Bertolt Brechtin näkemystä realistisen kirjoitustavan monimuotoisuudesta. ${ }^{35}$ On huomattava myös, että Jelinekin romaanissa kaikkia aikatasoja, tyylilajeja ja diskursseja yhdistää kertojan hahmo, joka epilogissa ottaa teatterinohjaajan roolin kutsuessaan historian kuolleita näyttämölle.

Kuolleet, olkaa hyvä ja tulkaa kaikki ulos monen perheen asunnoistanne Venäjällä, Puolassa ja taivas tietää missä loukoissa ne toimettomana lepäävätkin ja tänne minun luokseni näyttämölle. Nämä parantumattomat kuolleet! Tahtovat jatkuvasti hiipiä luoksemme, jotta hekin joskus voittaisivat. No, alkajaisiksi tämä ylösnouseminen sujui oikein hyvin, harjoitellaan vielä kerran, ja sitten on tosi edessä, sitten tulee suora lähetys. (KT, 652.) ${ }^{36}$

Romaanissa Die Kinder der Toten kauhufiktio ja komiikka, historia ja apokalypsis yhdistyvät viime kädessä teatteriesitykseksi, jolla on brechtiläinen tavoite vieraannuttaa ihmiset tutuksi kuvittelemastaan todellisuudesta. Jelinekin näytelmäkirjailijauran pohjalta ei ole yllättävää, että hänen romaaninsa muistuttaa postdraamallista teatteria, jossa yleisön tehtävä on koota esitys heterogeenisistä fragmenteista ja mielikuvista. ${ }^{37}$ Lukijoita puhutellaan kuten katsojia ja he osallistuvat produktioon, jossa uudelleenkirjoitetaan historiaa ja kansallisia identiteettejä. Samoin kuin postdraamallisessa teatterissa myös Jelinekin romaanissa aika ja tila esitetään uudella tavalla. Romaanin toistot, hidastukset ja aikatasojen vaihdokset tematisoivat ajan problematiikkaa ja intertekstuaaliset viittaukset ja konnotaatiot pakottavat lukijan yhdistämään mielessään historian ja nykypäivän. 


\section{Romaanin nythetki}

"Kaiken historian ja politiikan pohjalla on kysymys kuolevaisuuden torjumisesta. Taide kuitenkin on lähtöisin ja juurtuneena kommunikaatioon kuoleman ja kuolleiden kanssa. On kysymys siitä, että kuolleet saavat paikkansa. Juuri se on kulttuuria." (Heiner Müller: "Nekrofilia on rakkautta tulevaisuuteen”.). 38

Elfriede Jelinekin romaani Die Kinder der Toten ottaa voimakkaasti kantaa kysymykseen kollektiivisesta muistista ja unohtamisesta antaessaan Shoahin uhreja ja heidän jälkeläisiään käsittelevälle teokselle kauhukirjallisuuden muodon. Representaation sijaan historialliset tapahtumat konstruoidaan intertekstuaalisten viittausten ja sanaassosiaatioiden avulla. Jatkuvat rinnastukset 1940-luvun tapahtumien ja 1990-luvun tapahtumien välillä toimivat vieraannuttavasti ja paljastavat samalla historiallisen ääriilmiön ja nykytodellisuuden välisen yhteyden. Muistin sijaan romaanin kriittisen tarkastelun keskiöön nousee torjunta ja sen eri muodot. Lineaarisesti etenevän ajan korviketoimintoihin kuuluvat kansallista identiteettiä rakentavat diskurssit kuten luonto, viihde, urheilu ja matkailu. Jelinekin romaanissa kauhufiktion ja sen huipentuman, apokalypsiksen, keskeinen tavoite on tehdä torjuttu näkyväksi ja saada taiteen keinoin menneisyys ja nykyisyys sulautumaan toisiinsa lukijan tietoisuudessa.

Taiteen paluu todellisuuteen voi tapahtua monin tavoin, mutta se ei merkitse paluuta perinteiseen realismiin. Rothbergin $(2000,9)$ mukaan realismia, modernismia ja postmodernismia ei tulisi ajatella vain tyylisuuntina vaan ensisijaisesti erilaisina tapoina vastata historian haasteisiin. Siinä missä realismi dokumentoi tapahtumia, modernismi pohtii representaation rajoja ja postmodernismi huomioi aiheen yhteydet erilaisiin diskursseihin. Romanissa Die Kinder der Toten yhdistyvät nämä kaikki kolme tavoitetta siten, että postmodernia reflektiota täydentää postdraamallinen pyrkimys rikkoa raja taiteen tuottamisen ja vastaanottamisen välillä.

Nykykirjallisuudessa aaveet, vampyyrit ja zombiet toimivat edelleen osoituksena elämän ja kuoleman välisen rajan häilyvyydestä. Historiaan liittyvässä fiktiossa ne myös ilmentävät muistin valtaa unohduksen yli. Elfriede Jelinekin romaanissa historiallisen aavetarinan pohjalta paljastuu visio elävien velvollisuudesta ratkaista suhteensa menneisyyteen. Manatessaan Euroopan menneisyyden haamut nykypäivän näyttämölle Die Kinder der Toten luo romaanista muistitilan, jossa menneisyys ja nykyisyys yhdistyvät nythetkeksi.

\section{Viitteet}

1 'Die Geister der Toten, die solange verschwunden waren, sollen kommen und ihre Kinder grüssen.” Jelinekin romaanin hepreankielisen moton saksannoksesta ks. Lücke 2008, 95. Olen suomentanut kaikki lainaukset Jelinekin romaanista Die Kinder der Toten, johon viittaan 
jatkossa lyhenteellä KT. Samoin olen suomentanut Heiner Müller -sitaatin.

2 Theodor W. Adornon jyrkkä lausuma, jonka mukaan on barbariaa kirjoittaa runoutta Auschwitzin jälkeen, on peräisin vuodelta 1949. Kuten Ilona Reiners $(2001,195)$ huomauttaa, Adorno ei kuitenkaan halunnut kokonaan kieltää keskitysleirien kärsimyksen kuvausta taiteessa. Adorno arvosti esimerkiksi suuresti Paul Celanin runoutta ja Reiners $(2001,147)$ korostaakin, että hän näki taiteen nimenomaisena tehtävänä käsitellä sitä, minkä yhteiskunta torjuu tai marginalisoi. Adornon myöhemmistä näkemyksistä ks. myös Rothberg 2000, 25. ${ }^{3}$ Ks. Voßschmid 2010, 147-148.

${ }^{4}$ Teoksessa Illuminations Jetztzeit on käännetty ilmaukseksi "time of the now".

5 "Die Zeit besteht aus unendlich langen, schweren Peitschenschnüren, die über uns geschwungen werden."

6 "Auf einmal, völlig zwecklos, ist die Vergangenheit wieder da, unmöglich, sie zu lieben."

${ }^{7}$ Posttraumaattisista oireista ks. LaCapra 204, 117-118.

8 "Das Land braucht oben viel Platz, damit seine seligen Geister über den Wassern ordentlich schweben können. An manchen Stellen gehts über dreitausend Meter weit hinauf. Soviel Natur ist auf dieses Land verwendet worden, daß er seinerseits, vielleicht um seine Schuld an die Natur zurückzuzahlen, mit seinen Menschen immer recht freigebig umgegangen ist, und sie, kaum angebissen, auch schon wieder weggeworfen hat. Die großen Toten des Landes, um nur einige von ihnen zu nennen, heißen Karl Schubert, Franz Mozart, Otto Hayden, Fritz Eugen Letzter Hauch, Zita Zitter, Maria Theresiana, zuzüglich dem, was deren Militärakademie in Wiener Neustadt bis 1918 und in Stalingrad 1943 hervorgebracht hat und noch ein paar Millionen Zerquetschte."

${ }^{9}$ Annette Runte $(2008,123)$ liittää ruumiiden kammottavuuteen Julia Kristevan määritelmän abjektiudesta, epäpuhtaudesta, jota yritetään torjua minuuden ulkopuolelle.

10 ”Doch dieses Original, diese Karin Eins, hört unter dem Wasserklumpen, wie unten, tief drunten, eine Menschenmasse, ein Menschenmassiv, größer als die Schneealpe dort vorn, aus ihrer Erdendimension, aus diesem Disneyland unter Tau und Tag, heraufkommen möchte, eine Masse, die sich gar nicht erfassen läßt. Karin bittet verzweifelt, vergessen oder zumindest, bitte, nicht ergriffen zu werden von diesem Aufbruch des Massenhaften, von dieser dräuenden Unheimeligkeit."

11 "Wir sind ganz unter uns, und wo wir sind, da sind keine anderen."

12 ”Hinter der Rezeption stapeln sich Pappköffer zu Bergen, sperriges Stückgut, wie man es lang nicht mehr gesehn hat, eigentlich zu städtisch für dieses ländliche Reiseziel. Die meisten Gäste bevorzugen ja die modernen leichten Nylonrucksäcke, die sie dann gleich für ihre Ausflüge verwenden können. Die Wirtin hat solche Koffer aus Pappe seit ihrer Kindheit nicht mehr gesehen, als sie bei der Tante im Nachbarort, die damals schon Zimmer vermietete, ausgeholfen hat."

13 " Doch die Ewigkeit der Millionen, die auch tot sind, die hat kein Auge gesehn. Wie sind sie durch dieses enge Türl, das mit einer Selbstschließ-Automatik versehen ist, in den Saal gekommen, wo über ihre Wiederverkörperung verhandelt wird? Wieso sind nur drei von uns bis jetzt bei dieser Prüfung durchgekommen? Eine tote Seele ist vielleicht zuwenig, um für so viele zu sprechen."

14 "Achtung, ducken Sie sich, es beginnt der vorliegende Text. Er rutscht unter Ihren Händen weg."

15 ”[--] bis ER, ein neuer Golem, aufsteht und ungelenk sich wiegend, drehend, fußstampfend 
wieder einmal unseren Ländler zu tanzen beginnt."

16 ”[--] es wächst der Torso, der Golem, zu dem sich das Fleisch so wunderbar geformt hat, wieder zusammen [--]."

17 " [--] NICHT BETRETEN ZU DÜRFEN. Nur weil man IST!”.

${ }^{18}$ Bärbel Lücke $(2009$, 100) huomauttaa, että Steinhofin psykiatrisella klinikalla, jossa Elfriede Jelinekin isä kuoli, säilytettiin lähes meidän päiviimme saakka aivoja marmeladipurkeissa ja kuolleita formaliinialtaissa dokumentteina natsien tekemistä ihmiskokeista.

19 "Diese Leute sind, nachdem sie von unseren großen weichen Händern mütterlich nachgerechnet worden sind, ins Ferienlager abgesandt worden, wos Arbeit gratis gab, ARBEIT: kleiner! teurer! (wie die Euro-Banane). Zuerst wohnten sie hier, dann raus aus der Tür. Diese Tür ist ja schon beinahe eine Drehtür gewesen."

${ }^{20}$ Jutta Gsoels-Lorentzen $(2007,377)$ toteaa, että junat (die Züge) voivat esiintyä myös muiden sanojen osina kuten esim. "Anzüge" (vaatteet). Metaforisesti romaanissa puhutaan myös "ajan junasta", johon kaikkien on noustava: "Nouskaa junaan. Huomio! Juna lähtee." ("Alles einsteigen, Achtung Abfahrt!", KT, 613).

21 "Die Sprengungen damals in Mauthausen haben unseren gigantischen Berghang ein für allemal ins Rutschen gebracht [--].”

${ }^{22}$ Mautheisen kuului luokkaan III, mikä tarkoittaa sitä, että se oli tarkoitettu "parantumattomille poliittisille vastustajille". Siellä kuoli arviolta puoli miljoonaa ihmistä, erityisesti etnisiin ja poliittisiin vähemmistöihin kuuluvia intellektuelleja.

23 ”Da wären wir mit unserem Gas endlich an der richtigen Adresse gewesen [--]."

${ }^{24}$ Haiderista ks. lähemmin Mayer \& Koberg 2006, 200-202.

25 "Auch Herrn Eichmann, diesen Beamten, der den Menschen an Eingeweckte gegangen ist, um es nie mehr erwachen zu lassen, ist wahrscheinlich das Haar ausgefallen, ohne dass er mit diesem Riesenlager, das er mitsamt seinen Bürokollegen angleegt hatte, dann irgendwas hätte anfangen können. So leben wir in einer Lagergemeinschaft mit Körpern, Brillen, Zähnen, Koffern, Puppen, Plüschteddys von Fremden, ohne dass uns das etwas schaden oder nützen würde."

${ }^{26}$ Termin "negative symbiosis" esitti Hannah Arendt heti sodan jälkeen. Esseessään ”Negative Symbiosis. Germans and Jews after Auschwitz" Dan Diner huomauttaa, että joukkomurha on ollut itseymmärryksen alku sekä saksalaisille että juutalaisille. Ks. lähemmin Behrens 2002, 32. 27 "Wächst ihr die Hand aus dem Grab (wie dem Kind), daß man wieder weiß, wo sie bestattet ist?"

${ }^{28}$ Robert Lawson $(2003,22)$ huomauttaa, että kylmä sota auttoi ylläpitämään käsitystä Itävallasta kansallissosialismin uhrina. Juuri menneisyyden torjunta erottaakin hänen mukaansa itävaltalaisen ja saksalaisen kirjallisuuden.

${ }^{29}$ Romaanissa nimet "Botho" ja "Martin" viittaavat saksalaisiin kirjailijoihin, Botho Straussiin ja Martin Walseriin, jotka kumpikin julkisesti vastustivat holokaustin muistelemista. Saksan muistikiistoista ks. Fuchs \& Cosgrove 2006, 3-4.

30 "Wer immer all diese Hekatomben von Leuten vernichtet haben mag, er hat nicht bedacht, konnte vielleicht auch nicht wissen, daß sie mit ihrem Durchgang durchs Feuer eine dauernde Kraft erhalten würden, die jetzt mit uns, die wir noch da sind, zusammenwächst und uns, die hier uns brieflich an Sie wenden, in einem heulenden Wirbelsturm hinausreißt, wo uns keine Gedenkfeiern mehr finden werden, zu denen die Präsidenten und Kanzler sprechen, singen, trinken und lachen." 
31 ”[--] die Geschichte läuft immer schneller rückwärts, der Engel watet mit in Blut eingeweichtem und vor der Kamera mit Ariel-Ultra gewaschenem Gewand vorwärts, und wir Sieger mustern einander mit frisch gewaschenen, weichgespülten Blicken, wie zum ersten Mal."

${ }^{32}$ Barbara Lübcke $(2008,95)$ huomauttaa, että nimi Ariel ei viittaa vain mainoksista tuttuun pesuainemerkkiin, vaan myös Jerusalemissa hävitettyyn temppeliin.

33 ”[--] da kommen sie ja, die apokalyptischen Rösser vor ihrem original Wiener Fiaker!"

${ }^{34}$ Moster 2005, 87. "Kuolemanfuugan” tulkinnasta ks. Parry 2010, 83-84. Celanin hiusmotiivista vrt. Sabine Treude 1999, 107-108. Ks. myös romaanin sivut 627 ja 630.

${ }^{35}$ Realistisen kirjoitustavan laajuutta ja moninaisuutta käsittelevässä esseessään Brecht (1977, 340) nostaa realismin klassikkona tunnetun Honore de Balzacin edelle Percy Bysshe Shelleyn, joka runossaan "The Masque of Anarchy" kuvasi konkreettisia yhteiskunnallisia tapahtumia allegorian muodossa.

36 ”Die Toten alle jetzt bitte raus aus ihren Mehrfamilienunterkünften in Rußland, Polen und wer weiß in welchen Kaffs sie sonst noch untätig ruhen, und bitte, her zu mir, auf die Bühne! Diese unverbesserlichen Toten! Wollen dauernd zu uns hereinschlupfen, damit auch sie einmal gewinnen. Nun, für den Anfang war dieses Aufgehen schon recht gut, wir wollen es noch einmal proben, und dann wird es ernst, dann gehen wir auf Sendung."

${ }^{37}$ Hans-Thies Lehmannin $(2009$, 423) mukaan postdraamallinen teatteri on korostetusti sosiaalista taidetta, jonka poliittisuus on nimenomaan havainnoimisen politiikkaa.

38 ”Die gesamte Geschichte und Politik reduziert sich auf die Verdrängung der Sterblichkeit. Kunst aber stammt und wurzelt in der Kommunikation mit dem Tod und den Toten. Es geht darum, dass die Toten einen Platz bekommen. Das ist eigentlich Kultur. (Heiner Müller: Nekrophilie ist Liebe zur Zukunft)" Lainaus on peräisin Heiner Müllerin keskustelusta Fritz M. Raddatzin kanssa. Ks. lähemmin Philipsen 2008, 13.

\section{Lähteet}

ADORnO, THEOdOR W. I 996: Negative Dialektik. Frankfurt am Main: Suhrkamp. ADORNO, THEODOR W I977: Gesammelte Schriften 10. Frankfurt am Main: Suhrkamp. baer, elisabeth 20i2: The Golem Redux. From Prague to Post-Holocaust Fiction. Detroit: Wayne State University Press Detroit.

BeHrens, KATJA 2002: The Rift and Not the Symbiosis. Unlikely History. The Changing German-Jewish Symbiosis 1945-2000. Ed. Leslie Morris \& Jack Zipes. New York: Palgrave.

BIEBUyCK, BENJAMIN \& GUNTER MARTENS 2008: Metonymia in memoriam. Die Figürlichkeit inszenierter Vergessens- und Erinnerungsdiskurse bei Grass und Jelinek. Literatur im Krebsgang. Totenbeschwörung und memoria in der deutschsprachigen Literatur nach 1989. Hg. Arne de Winde \& Anke Gilleir. Amsterdam, New York: Rodopi. BenJAmin, WAlter I 992: Illuminations. (Schriften 1955). Ed. Hannah Arendt. Trans. Harry Zahn. London: Fortuna Press.

BRECHT, BERTOLt i 977: Gesammelte Werke, Bd.10. Frankfurt am Main: Suhrkamp. Brogan, KathleEn i 998: Cultural Haunting. Ghosts and Ethnicity in Recent American 
Literature. Charlottesville \& London: University Press of Virginia.

CARPIO, GLENDA R. 2008: Laughing Fit To Kill. Black Humor in the Fictions of Slavery.

New York: Oxford University Press.

Derrida, JACQues 2006: The Spectres of Marx (Spectres de Marx, 1993). New York:

Routledge.

FOSTER, HAL I996: The Return of the Real. The Avant-Garde at the End of the Century.

Cambridge: The MIT Press.

FREUD, SIGMUND 2005: Murhe ja melankolia sekä muita kirjoituksia. (Gesammelte Schriften, 1924-34). Suom. Markus Lång. Tampere: Vastapaino.

fritsch, matthias 2005: The Promise of Memory. History and Politics in Marx, Benjamin and Derrida. New York: State University of New York Press.

FUCHS, ANNE \& COSGROvE MARY 2006: Introduction: Germany's Memory Contests and the Management of the Past. German Memory Contests. The Quest for Identity in Literature, Film and Discourse since 1990. Ed. Anne Fuchs et al. Rochester: Camden House. gsoels-lorensen, JutTa 2007: Elfriede Jelinek's Die Kinder der Toten: Representing the Holocaust as an Austrian Ghost Story. The Germanic Review (reprint) 81 (4), 360382.

HIRSCH, MARIANNe 20I2: The Generation of Post-Memory. Writing and Visual Culture After the Holocaust. New York: Columbia University Press.

JeLineK, Elfriede 1997/I995: Die Kinder der Toten. Reinbek bei Hamburg: Rowohlt. JELINEK, ELFRIEDE 2O I 2: Ich als Toten-Ausgräberin. Jelinek(Jahr)Buch. Elfriede JelinekForschungszentrum. Wien: Praesens-Verlag.

JELINEK, ELFRIEDE \& ANDRÉ MÜLLER 2006: "Ich bin die Liebesmüllabfuhr". Stets das Ihre Elfriede Jelinek. Arbeitsbuch. Hg. Brigitte Landes. Wien: Theater der Zeit.

LACAPRA, DOMINICK 2004: History in Transit. Experience, Identity, Critical Theory. Ithaca and London: Cornel University Press.

LAWSON, ROBERT 2003: Role Reversal and Passing in Postwar German and Austrian Jewish Literature. Osnabrück: Der andere Verlag.

Lehmann, hans-Thies 2009: Draaman jälkeinen teatteri (Postdramatisches Theater, 1999). Suom. Riitta Virkkunen. Helsinki: Like.

LÜCKe, BARBARA 2008: Elfriede Jelinek. München: Wilhelm Fink Verlag.

MAYer, Verena \& ROLAND KOBERg 2006: Elfriede Jelinek. Ein Porträt. 2.p. Reinbek bei Hamburg: Rowohlt.

Meteling, ARno 20io: Genius Loci: Memory, Media and the Neo-Gothic bei George Klein und Elfriede Jelinek. Popular Ghosts. The Haunted Space of Everyday Culture. Ed. Maria del Pilar Blanco \& Esther Peeren. New York: The Continuum.

moster, STefan 2005: Puiden lohtu. Saksankielistä runoutta 1946-2000. Valikoinut ja toimittanut Stefan Moster. Helsinki: WSOY. 
ORTNER, JeSSICA 20 I 2: Aspekte des Untoten in Elfriede Jelineks Roman Die Kinder der Toten. Erinnerungsästhetische und narratologische Überlegungen. Jelinek(Jahr)Buch. Elfriede Jelinek-Forschungszentrum. Wien: Praesens-Verlag.

PARRY, CHRISTOPH 20IO: Paul Celan ja muistamisen poetiikka. Muistijälkiä. Esseitä saksankielisestä nykykirjallisuudesta. Toim. Lotta Kähkönen \& Hanna Meretoja. Helsinki: Avain.

patha, Marcus g 20 Io: Wege des Lachens. Jüdischer Humor und Witz aus Wien. Weitra: Bibliothek der Provinz.

PHILIPSEN, BART 2008: Literatur und Spektralität: zur Einführung. Literatur im Krebsgang. Totenbeschwörung und memoria in der deutschsprachigen Literatur nach 1989. Hg. Arne de Winde \& Anke Gilleir. Amsterdam \& New York: Rodopi.

reiners, ilona 200I: Taiteen muisti. Tutkielma Adornosta ja Shoahista. Helsinki: Tutkijaliitto.

Rothberg, Michael 2000: Traumatic Realism. The Demands of Holocaust Representation. Minneapolis: The University of Minnesota Press.

RUNTE, ANNETTE 2008: 'Kinder der Un/Toten'. Zu Elfriede Jelineks 'Versprechen' zwischen Satire und Allegorie. Elfriede Jelinek. Sprache, Gesellschaft und Herrschaft. Hg. Franzoise Rétif \& Johann Sonnleitner. Würzburg: Königshausen-Neumann.

treude, Sabine i 999: Die Kinder der Toten oder: Eine Verwicklung der Geschichte mit einer Geschichte die fehlt. Text + Kritik 117, 100-109.

voßsснміDт, LIISA 20Iо: Elfriede Jelinek - kiistelty yhteiskuntakriitikko ja kielen virtuoosi. Muistijälkiä. Esseitä saksankielisestä nykykirjallisuudesta. Toim. Lotta Kähkönen \& Hanna Meretoja. Helsinki: Avain.

ZAngl, veronika 2009: Poetik nach dem Holocaust. Erinnerungen - Tatsachen Geschichten München: Wilhelm Fink Verlag. 